\title{
Prevalence of work-related musculoskeletal symptoms and associated risk factors among domestic gas workers and staff of works department in Enugu, Nigeria: a cross-sectional study
}

Chinenye Doris Oluka ${ }^{1,2}$ (D) Esther Obidike ${ }^{2,3}$, Antoninus Obinna Ezeukwu² (D), Ogochukwu Kelechi Onyeso ${ }^{2,4}$ (D) and Echezona Nelson Dominic Ekechukwu ${ }^{2,5^{*}}$ (i)

\begin{abstract}
Background: The impact of work-related musculoskeletal symptoms (WMSS) permeates various occupations. Objective: To compare WMSS and associated risk factors among domestic gas workers (DGWs) and staff of Works Department (SWD) in Enugu.

Methods: One-hundred adults ( $D G W=50, S W D=50$ ) participated in this cross-sectional study. The Nordic Musculoskeletal Questionnaire and a demographics questionnaire were used to assess the prevalence of WMSS and related risk factors. Data were analysed using independent $t$-test or Mann-Whitney $U$, chi-square, and logistic regression at $p<0.05$.

Results: The DGWs $(86 \%)$ had a significantly $(x 2=24.45, p<0.001$ ) higher WMSS than the SWD (38\%). Lower-back (54\%) and shoulder (52\%) were the most affected body parts among the DGWs in comparison to the hips/thighs (20\%) among the SWD. Work-related factors such as daily work-duration $(x 2=75.44, p<0.001)$, lifting training $(x 2=$ $96.24, p<0.001)$, and use of personal protective equipment (PPE) of facemask $(x 2=100.0, p<0.001)$ and gloves $(X 2=96.09, p<0.001)$ were significantly associated with general WMSS among the DGWs. However, diastolic blood pressure (DBP) $(\mathrm{OR}=1.29, p=0.018)$, work duration $>8 \mathrm{~h} /$ day $(\mathrm{OR}=0.001, p=0.028)$, female gender $(\mathrm{OR}=6.98-$ $10.26, p<0.05)$, sleep duration $<6 \mathrm{~h} /$ day $(\mathrm{OR}=0.56-0.73, p<0.05)$ and poor exercise behaviour $(\mathrm{OR}=0.15, p=$ 0.013 ) were the identified independent risk factors of WMSS among DGWs, while DBP (OR $=0.99, p=0.012)$ and female gender $(\mathrm{OR}=6.47, p=0.032$ ) were the only identified independent risk factors for SWD.

\footnotetext{
* Correspondence: nelson.ekechukwu@unn.edu.ng

${ }^{2}$ Department of Medical Rehabilitation, Faculty of Health Sciences and Technology, College of Medicine, University of Nigeria, Enugu, Nigeria ${ }^{5}$ LANCET Physiotherapy Wellness and Research Centre, Enugu, Nigeria Full list of author information is available at the end of the article
}

C C The Author(s). 2020 Open Access This article is licensed under a Creative Commons Attribution 4.0 International License, which permits use, sharing, adaptation, distribution and reproduction in any medium or format, as long as you give appropriate credit to the original author(s) and the source, provide a link to the Creative Commons licence, and indicate if changes were made. The images or other third party material in this article are included in the article's Creative Commons licence, unless indicated otherwise in a credit line to the material. If material is not included in the article's Creative Commons licence and your intended use is not permitted by statutory regulation or exceeds the permitted use, you will need to obtain permission directly from the copyright holder. To view a copy of this licence, visit http://creativecommons.org/licenses/by/4.0/ The Creative Commons Public Domain Dedication waiver (http://creativecommons.org/publicdomain/zero/1.0/) applies to the data made available in this article, unless otherwise stated in a credit line to the data. 
(Continued from previous page)

Conclusion: WMSS is significantly higher among DGWs than the SWD. High DBP, female gender, working beyond $8 \mathrm{~h}$ per day, sleeping less than $6 \mathrm{~h}$ per day, and insufficient exercise increase the risks of WMSDs, especially among the DGWs. To mitigate the adverse effects of WMSDs, SWD and DGWs require break and leave periods, PPE and assistive devices, exercise, medical check-up, and workplace ergonomics.

Keywords: Ergonomics, Exercise, Manual handling, Personal protective equipment, Prevalence, Shift duty, Musculoskeletal disorders

\section{Background}

Greater than $9 \%$ of the global adult population suffers from physical disabilities caused by musculoskeletal disorders (MSDs). This prevalence is higher among women and increases markedly with age, accounting for $2 \%$ of global economic disease burden [1]. MSDs are usually related to work and interfere with health status, quality of life, and work-efficiency among individuals [2]. Workrelated musculoskeletal symptoms (WMSS) are among the most significant occupational hazards in many industries [3]. In addition, WMSS have negative socioeconomic impact on individuals, organisations, and the society [4]. The risk factors of WMSS can broadly be categorised into mechanical and psychosocial factors. The mechanically-induced WMSS is associated with poor working conditions among manual workers [5-7]. Work-related musculoskeletal symptoms can also be caused by cumulative task-related musculoskeletal trauma arising from manual handling activities $[4,8]$.

Domestic Gas Workers (DGW) in Enugu metropolis are mostly employed in privately-owned liquefied natural gas (methane) stations. Due to the continuous demand for liquefied natural gas because of its usefulness in domestic cooking, bakeries, restaurants, and medium-scale industries, DGWs have to work daily, usually without any shifts. Gas cylinder refilling is a strenuous job, mostly associated with forceful exertion [9, 10]. In addition, DGWs often engage in manual handling activities such as lifting, bending, carrying, and repetitive movements [6]. It involves unloading and conveyance of the empty gas cylinders to the point where it would be refilled, filling and weighing the gas cylinders, testing for any valve leakages, and retuning the filled cylinders back to the customers.

Similarly, Staff of Works Department (SWD) in many tertiary institutions in Enugu engage in manual material handling such as maintenance of automobile, mechanical, and electrical installations, sweeping, mowing of lawns, cleaning of offices, and hostels. The staff of the Works Department of the University of Nigeria Enugu Campus (UNEC) and University of Nigeria Teaching Hospital (UNTH) Enugu mainly perform manual handling jobs. Their job demands a high level of physical strength, postural adaptations, and a relatively lesser amount of rest, which makes them vulnerable to MSD [11]. In this study, the researchers hypothesised that the SWD in tertiary institutions are exposed to similar WMSS risk-factors as in the case of DGWs. Therefore, this study compared the prevalence of WMSS among DGWs in Enugu metropolis and age- and sex-matched SWD in two tertiary institutions (UNEC and UNTH) in Enugu, Nigeria.

\section{Methods \\ Participants}

This cross-sectional exploratory research involved 100 participants (16 females and 84 males) recruited from domestic gas stations in Enugu Metropolis and from the Works Department of UNEC and UNTH in Enugu between July 1 and August 23, 2019. Fifty DGWs were conveniently recruited using the eligibility criteria and classified according to their sex and age ranges with a class-width of 3 years. Correspondingly, 50 sex- and agematched SWD were purposively recruited to match the sample of DGW. The matching protocol was adapted from a recently published study among diabetic patients [12]. All the participants met the inclusion criteria and provided written informed consent for participation in the study.

The inclusion criteria were as follows: being a registered DGW under the Cooking Gas Workers' Association Enugu or personnel on nominal roll of the Works Department of UNEC and UNTH; age range between 18 and 50 years; and absence of cardiopulmonary diseases, physical disability, psychiatric and psychological disorders. Potential participants who smoke and those with prior diagnosis of idiopathic-pain; complex regional pain syndrome; chronic stress and anxiety disorders; retinopathy; and neurological, vascular, cardiac, renal, respiratory, and rheumatoid diseases were excluded from the study.

A minimum sample size of 96 was calculated at $95 \%$ power, 0.05 level of error, an effect size of 0.73 with an equal allocation ratio (1:1), under two tails independent t-test using $G^{*}$ power 3.0.10 software. However, a total of 100 (50 in each group) participants were recruited for this study. Ethical approval for this study was obtained 
from the Research and Ethics Committee of the University of Nigeria Teaching Hospital, Enugu State, Nigeria.

\section{Research instruments}

The research instruments used in this study include stadiometer and weighing scale for assessing the height and weights of the participants as well as the estimation of their body mass index (BMI). Others were sphygmomanometer and stethoscope (for assessing blood pressure), stopwatch, numerical pain rating scale (NPRS), the Nordic Musculoskeletal Questionnaire, and a self-developed but validated questionnaire for assessing work-related risk factors.

Nordic Musculoskeletal Questionnaire (NMQ) was developed by Kuorinka et al. [13] to assess regional and general MSD. It contained a body map to indicate nine symptom sites: neck, shoulders, upper back, elbows, low back, wrist or hands, hips or thighs, knees, and ankle feet. The questionnaire also captured data on the incidence of musculoskeletal symptoms in the last 7 days and 12 months. It also obtained information on whether the musculoskeletal symptoms had prevented the respondent from carrying out normal daily activities and whether the respondent had consulted a physician for MSD in the last 1 year. The test-retest reliability of NMQ is about 0.8 . Its sensitivity ranges between 66 and $92 \%$, and its specificity is between 71 and $88 \%[13,14]$.

The present researchers developed a two-part, faceand content-validated, semi-structured questionnaire to collect data on the participants' demographics and workrelated WMSS risk factors. Part A was designed to record the participants' age, sex, height, weight, BMI, and cardiopulmonary parameters. Part B consisted of eight items. Items 1 to 4 were open-ended questions designed to collect information on duration of service (years), work frequency (days per week), daily work duration (hours), and daily sleep duration (hours). Items 5 to 8 were dichotomous (yes or no) questions designed to determine whether the respondents exercised regularly, used personal protective equipment (PPE) while working, had training on ergonomics, and observed shift- or off-duty and break periods. The validation panel consisted of five experts in MSD; they interacted twice through the Delphi method of e-mail exchanges before arriving at the consensus on the face and content validity of the instrument.

\section{Procedures and measurements}

Firstly, the protocol for the study was explained to the participants, and their informed consents were sought and obtained. The researcher-made questionnaire was administered to the participants, and the completed questionnaire was retrieved and stored.
Secondly, the participants' height $(\mathrm{m})$ and weight $(\mathrm{kg})$ were measured using a standard BMI apparatus (RGZ120, made in China; weight $\left./[\text { height }]^{2}=\mathrm{BMI}\right)$ and protocol [15]. Musculoskeletal pain intensity was obtained using NPRS, which rates pain from 1 (least pain) to 10 (worst pain). For participants with multiple painful regions, the intensity of the most painful region was recorded.

Thirdly, the cardiovascular parameters were measured three times, and the median score was recorded. The systolic and diastolic blood pressure $(\mathrm{mmHg})$ were measured after $5 \mathrm{~min}$ of rest, using mercury sphygmomanometer (Accoson mercury, made in the United Kingdom) and stethoscope (Litman, made in the United States). The blood pressure was measured from the left brachial artery in a sited position with the left elbow flexed at the level of the heart. Then, the resting heart rate (RHR) in beats per minute (bpm) and respiratory rate $(\mathrm{RR})$ in cycles per minute $(\mathrm{cpm})$ were measured and recorded using a stopwatch (Kadio, made in China).

Finally, the NMQ was administered to assess the prevalence of WMSS. The questionnaire presented a figure of the human body with nine anatomical regions to assist the participants to mark the corresponding regions of their body on which they had MSD symptoms (aches, pains, discomfort or numbness) in the last 7 days and the last 12 months.

\section{Data analysis}

The data obtained were processed and analysed using statistical package for social sciences (SPSS) version 20 software. Descriptive statistics - frequency (percentage), mean \pm standard deviation and median (range) were used to summarise the demographic characteristics and prevalence of WMSS among the participants. Test of normality for the continuous variables measured on a ratio scale was done using Shapiro-Wilks test. Independent $t$-test and Mann-Whitney $U$ test were used to respectively compare normally and non-normally distributed variables. The Chi-square test was used to compare the categorical variables and to test for association between WMSS and some selected risk factors within the two groups. Multilevel logistic regression modelling was used to predict the occurrence of WMSS. The level of significance was set at $p \leq 0.05$.

\section{Results}

Demographic details of the domestic gas workers (DGWs) and staff of works department (SWD)

The study involved 100 participants who were divided into two study groups (DGWs and SWD), each with equal number (50) of participants. Table 1 presents the demographic characteristics of all participants. Each group comprised $8(16 \%)$ women and $42(84 \%)$ men, with 
Table 1 Demographic Characteristics of the Domestic Gas Workers and Staff of Works Department $(n=100)$

\begin{tabular}{|c|c|c|c|c|c|c|}
\hline \multirow[t]{2}{*}{ Variable } & \multicolumn{3}{|c|}{$f(\%) /$ Mean \pm SD / Median [Range] } & \multirow[t]{2}{*}{ M.D } & \multirow{2}{*}{$\begin{array}{l}x^{2} / \\
\text { t-score }\end{array}$} & \multirow[t]{2}{*}{$p$-value } \\
\hline & Total $(n=100)$ & $\mathrm{DGW}(n=50)$ & $\operatorname{SWD}(n=50)$ & & & \\
\hline \multicolumn{7}{|l|}{ Gender } \\
\hline Male & $84(84)$ & $42(84)$ & $42(84)$ & - & $0.001^{\mathrm{a}}$ & 1.000 \\
\hline Female & $16(16)$ & $8(16)$ & $8(16)$ & - & & \\
\hline Age (years) & $31.95 \pm 8.80$ & $31.74 \pm 8.24$ & $32.16 \pm 0.60$ & -0.42 & $-0.360^{\mathrm{b}}$ & 0.720 \\
\hline Height (m) & $1.70[0.23]$ & $1.70[0.18]$ & $1.70[0.23]$ & - & - & 0.233 \\
\hline Weight (kg) & $76.34 \pm 8.29$ & $74.36 \pm 9.11$ & $78.32 \pm 6.91$ & -3.96 & $-2.448^{\mathrm{b}}$ & $0.016^{*}$ \\
\hline BMI $\left(\mathrm{kg} / \mathrm{m}^{2}\right)$ & $25.66[18.01]$ & $25.37[18.01]$ & $25.95[14.68]$ & - & - & $0.023^{*}$ \\
\hline $\mathrm{SBP}(\mathrm{mmHg})$ & $120.00[50.00]$ & $110.00[40.00]$ & $120.00[50.00]$ & - & - & $0.002^{*}$ \\
\hline $\mathrm{DBP}(\mathrm{mmHg})$ & $79.00[30.00]$ & $74.00[35.00]$ & $80.00[30.00]$ & - & - & 0.443 \\
\hline $\mathrm{RR}(\mathrm{cpm})$ & $22.00[12.00]$ & $22.50[7.00]$ & $21.50[12.00]$ & - & - & 0.105 \\
\hline RHR (bpm) & $74.00[78.00]$ & $74.00[35.00]$ & $73.00[68.00]$ & - & - & 0.675 \\
\hline Duration of service (years) & $2.00[39.92]$ & 1.75 [39.92] & 5 [39.50] & - & - & $<0.001^{*}$ \\
\hline Work duration (hours/day) & $8.00[8.00]$ & $10.00[7.00]$ & $8.00[2.00]$ & - & - & $<0.001^{*}$ \\
\hline Sleep duration (hours/day) & $6.00[2.00]$ & $6.00[1.00]$ & $5.00[2.00]$ & - & - & 0.859 \\
\hline
\end{tabular}

no significant differences in sex distribution between the groups $\left(\chi^{2}<0.001, p=1.000\right)$. Similarly, there was no significant difference between the mean ages of the DGWs and SWD $(t=-0.360, p=0.720)$.

\section{Prevalence of WMSS among the domestic gas workers (DGW) and staff of works department (SWD)}

The 12-month general WMSS prevalence for the entire population was $62 \%(\mathrm{DGWs}=86 \%, \mathrm{SWD}=38 \%)$. The general WMSS prevalence among DGWs was significantly higher than that in the SWD $\left(X^{2}=24.45, p<\right.$ $0.001)$. The majority of the DGWs $(50 \%)$ had WMSS in at least 3 regions of their body, whereas only $6 \%$ of SWD had WMSS in 3 or more regions of their body. The regional WMSS occurrence reported in Table 2 revealed that the low back (54\%) and shoulder (52\%) were the most affected sites among the DGWs, whereas the hips/thighs (20\%) were the most affected body part among the SWD. When compared with the SWD, the DGWs had significantly higher prevalence of shoulder WMSS $\left(X^{2}=18.38, p<0.001\right)$, upper back $\left(X^{2}=18.78\right.$, $p<0.001)$, elbow $\left(X^{2}=12.71, p<0.001\right)$ and lower back $\left(X^{2}=33.53, p<0.001\right)$. However, no significant difference was observed in the WMSs prevalence of the neck $\left(X^{2}=\right.$ $0.71, p=0.68)$, wrist and hand $\left(X^{2}=2.17, p=0.269\right)$, hip and thigh $\left(X^{2}=0.51, p=0.64\right)$, knees $\left(X^{2}=0.001, p=\right.$ $1.00)$, and ankle/foot $\left(X^{2}=0.344, p=1.00\right)$.

A good number of the participants described their pain as moderate intensity on the numerical pain rating scale $(\mathrm{DGWs}=50 \%, \mathrm{SWD}=16 \%)$. Pain intensity was significantly higher in DGWs group than in the SWD group $\left(X^{2}=25.02, p<0.001\right)$.

Work-related risk factors of WMSS among domestic gas workers (DGW) and staff of works department (SWD)

A significantly greater number of DGWs (76.0\%) reported being exposed to higher work frequency ( $\geq 6$ days per week) compared to the few reports from the SWD (6\%), $\left(X^{2}=82.02, p<0.001\right)$. All the participants in the SWD were government-employed workers; most of whom (90\%) worked only on weekdays (maximum of 5 days per week), while the rest had shift-duty, which sometimes falls into the weekend. Shift-duty was significantly higher among the SWD than the DGWs $\left(X^{2}=\right.$ $10.75, p=0.002)$. Compared to the SWD, majority of the DGWs did not use PPE such as facemask (84\% vs 30\%) and gloves ( $84 \%$ vs $2 \%$ ), had no training on lifting techniques (68\% vs $10 \%)$, and did not exercise regularly (70\% vs $42 \%)$. A significantly greater proportion of the SWD underwent lifting technique training $\left(X^{2}=96.24\right.$, $p<0.001)$, as well as used PPE of facemask $\left(X^{2}=100.0\right.$, $p<0.001)$ and gloves $\left(X^{2}=96.09, p<0.001\right)$ than the DGWs as shown in Table 3.

\section{Association between WMSS and selected variables among domestic gas workers (DGWs) and staff of works department (SWD)}

There was a significant association between general WMSS and each of diastolic blood pressure level $\left(x^{2}=\right.$ 20.79, $p=0.004)$, training on lifting techniques $\left(X^{2}=\right.$ 
Table 2 Comparison of the Prevalence of Work Related Musculoskeletal Disorders among Domestic Gas Workers and Staff of Works Department $(n=100)$

\begin{tabular}{|c|c|c|c|c|c|}
\hline \multirow[t]{2}{*}{ Variable } & \multicolumn{3}{|c|}{ frequency (\%) } & \multirow{2}{*}{$\begin{array}{l}x^{2}- \\
\text { score }\end{array}$} & \multirow[t]{2}{*}{$p$-value } \\
\hline & $\begin{array}{l}\text { DGW } \\
(n=50)\end{array}$ & $\begin{array}{l}\text { SWD } \\
(n=50)\end{array}$ & $\begin{array}{l}\text { Total } \\
(n=100)\end{array}$ & & \\
\hline General WMSD Prevalence & $43(86)$ & $19(38)$ & $62(62)$ & 24.45 & $<0.001^{*}$ \\
\hline \multicolumn{6}{|l|}{ Number of WMSD regions } \\
\hline 1 & $9(18)$ & $12(24)$ & $21(21)$ & 39.16 & $<0.001^{*}$ \\
\hline 2 & $10(20)$ & $5(10)$ & $15(15)$ & & \\
\hline 3 & $13(26)$ & $2(4)$ & $15(15)$ & & \\
\hline$>4$ & $12(24)$ & $1(2)$ & $13(13)$ & & \\
\hline \multicolumn{6}{|l|}{ Regional WMSD Prevalence } \\
\hline Neck WMSD & $2(4)$ & $4(8)$ & $6(6)$ & 0.71 & 0.680 \\
\hline Shoulder WMSD & $26(52)$ & $6(12)$ & $32(32)$ & 18.38 & $<0.001^{*}$ \\
\hline Upper back WMSD & $18(36)$ & $1(2)$ & $19(19)$ & 18.78 & $<0.001^{*}$ \\
\hline Elbow WMSD & $19(38)$ & $4(8)$ & $23(23)$ & 12.71 & $<0.001^{*}$ \\
\hline Wrist/hand & $6(12)$ & $2(4)$ & $8(8)$ & 2.71 & 0.269 \\
\hline Lower back & $27(54)$ & $1(2)$ & $28(28)$ & 33.53 & $<0.001^{*}$ \\
\hline Hips/thighs & $13(26)$ & $10(20)$ & $23(23)$ & 0.51 & 0.640 \\
\hline Knees & $4(8)$ & $4(8)$ & $8(8)$ & 0.001 & 1.000 \\
\hline Ankles/foot & $1(2)$ & $2(4)$ & $3(3)$ & 0.34 & 1.000 \\
\hline Activity limitation & $8(16)$ & $1(2)$ & $9(9)$ & 5.98 & $0.031^{*}$ \\
\hline Has seen a physician in the last 1-year & $9(18)$ & $2(4)$ & $11(11)$ & 5.01 & 0.051 \\
\hline Pain intensity (NPRS) & & & & 25.02 & $<0.001^{*}$ \\
\hline None & $9(18)$ & $32(64)$ & $41(41)$ & & \\
\hline Low $(1-4)$ & $11(22)$ & $4(8)$ & $15(15)$ & & \\
\hline Moderate (5-6) & $25(50)$ & $8(16)$ & $33(33)$ & & \\
\hline High (7-10) & $5(10)$ & $6(12)$ & $11(11)$ & & \\
\hline
\end{tabular}

DGW Domestic Gas Workers, SWD Staff of Works Department, WMSD Work-Related Musculoskeletal Disorders, NPRS Numerical Pain Rating Scale

* = significant (2-tailed) test at $p<0.05$

2.36, $p=0.036)$, use of $\operatorname{PPE}(\mathrm{x} 2=7.64, p=0.022)$ and daily work duration $(\chi 2=21.06, p=0.007)$ among the DGWs. Among the SWD, gender $\left(\chi^{2}=5.53, p=0.027\right)$, work frequency $\left(\chi^{2}=9.06, p=0.011\right)$ and daily work duration $\left(x^{2}=5.86, p=0.05\right)$ were significantly associated with general WMSS as shown in Tables 4 and 5 .

Among the DGWs, there was a significant association between shoulder WMSS and each of age $\left(\chi^{2}=41.70\right.$, $p=0.003)$, sex $\left(x^{2}=7.39, p=0.008\right)$, height $\left(\chi^{2}=27.16\right.$, $p=0.012)$, respiratory rate $(\mathrm{X} 2=15.85, p=0.027)$, sleep duration $(\mathrm{X} 2=26.80, p<0.001)$, and exercise status $(\mathrm{X} 2=$ $5.51, p=0.020)$. Conversely, there was no significant association between these participants variables and shoulder WMSS among the SWD $(p>0.05)$ as shown in Tables 4 and 5.

Lastly, there was a significant association between low back WMSS and each of age $\left(\chi^{2}=36.00, p=0.020\right)$, sex $(\mathrm{x} 2=8.00, p=0.006)$, height $(\mathrm{x} 2=25.00, p=0.020)$, diastolic blood pressure $\left(\chi^{2}=14.40, p=0.040\right)$ and sleep duration $\left(\chi^{2}=31.30, \quad p<0.001\right)$ among the DGW.
Among the SWD, only age $\left(\mathrm{X}^{2}=50.00, p=0.002\right)$ and years of service $\left(\chi^{2}=50.00, p<0.001\right)$ were significantly associated with WMSS around the low back region as shown in Tables 4 and 5.

Predictors of WMSS among domestic gas workers (DGWs) and staff of works department (SWD)

A multi-level logistic regression was performed to ascertain the effects of sex, blood pressure, training on lifting technique, work frequency, and daily work duration on the likelihood that participants (DGWs and SWD) have musculoskeletal symptoms in any part of their body (general WMSS). The model for both groups was significant and explained 76.0 and 22\% (Nagelkerke $R^{2}$ ) of the variance in general WMSS and it correctly classified 92.0 and $70.0 \%$ of cases for the DGWs and SWD respectively. Higher diastolic blood pressure $(\mathrm{OR}=1.29, p=0.018)$ and working beyond $8 \mathrm{~h}$ per day $(\mathrm{OR}<0.01, p=0.028)$ were the independent predictors of general WMSS among the DGWs. Among the SWD, diastolic blood 
Table 3 Comparison of Work-related risk factors of WMSD among Domestic Gas Workers and Staff of Works Department $(n=100)$

\begin{tabular}{|c|c|c|c|c|c|}
\hline \multirow[t]{2}{*}{ Variables } & \multicolumn{3}{|c|}{ frequency (\%) } & \multirow{2}{*}{$\begin{array}{l}x^{2}- \\
\text { score }\end{array}$} & \multirow[t]{2}{*}{$p$-value } \\
\hline & $\begin{array}{l}\text { DGW } \\
(n=50)\end{array}$ & $\begin{array}{l}\text { SWD } \\
(n=50)\end{array}$ & $\begin{array}{l}\text { Total } \\
(n=100)\end{array}$ & & \\
\hline \multicolumn{6}{|c|}{ Work frequency (days/week) } \\
\hline$\leq 4$ & $0(0)$ & $0(0)$ & $0(0)$ & 82.02 & $<0.001^{*}$ \\
\hline 5 & $0(0)$ & $45(90)$ & $45(45)$ & & \\
\hline 6 & $38(76)$ & $3(6)$ & $41(41)$ & & \\
\hline 7 & $12(24)$ & $2(4)$ & $14(14)$ & & \\
\hline \multicolumn{6}{|c|}{ Rest break (compliance) } \\
\hline No & $48(96)$ & $44(88)$ & $92(92)$ & 2.17 & 0.269 \\
\hline Yes & $2(4)$ & $6(12)$ & $8(8)$ & & \\
\hline \multicolumn{6}{|c|}{ Training on lifting technique } \\
\hline No & $34(68)$ & $5(10)$ & $39(39)$ & 96.24 & $<0.001^{*}$ \\
\hline Yes & $16(32)$ & $45(90)$ & $61(61)$ & & \\
\hline \multicolumn{6}{|c|}{ Duty shifts } \\
\hline No & $45(90)$ & $31(62)$ & $76(76)$ & 10.75 & $0.002^{*}$ \\
\hline Yes & $5(10)$ & $19(38)$ & $24(24)$ & & \\
\hline \multicolumn{6}{|c|}{ Use of PPE(face mask) } \\
\hline No & $41(84)$ & $15(30)$ & $56(56)$ & 100.00 & $<0.001^{*}$ \\
\hline Yes & $9(18)$ & $35(70)$ & $44(44)$ & & \\
\hline \multicolumn{6}{|c|}{ Use of PPE(gloves) } \\
\hline No & $41(84)$ & $1(2)$ & $42(42)$ & 96.09 & $<0.001^{*}$ \\
\hline Yes & $9(18)$ & 49(98) & $58(58)$ & & \\
\hline \multicolumn{6}{|c|}{ Exercise status } \\
\hline No & $35(70)$ & $21(42)$ & $56(56)$ & 7.95 & $0.005^{*}$ \\
\hline Yes & $15(30)$ & $29(58)$ & $44(44)$ & & \\
\hline
\end{tabular}

DGW Domestic Gas Workers, SWD Staff of Works Department, WMSD Work-Related Musculoskeletal Disorders, PPE Personal Protective Equipment (face mask, hand glove)

$*=$ significant $(2$-tailed) test at $p<0.05$ pressure $(\mathrm{OR}=0.99, p=0.012)$ and female gender $(\mathrm{OR}=$ 6.47, $p=0.032$ ) were the independent predictors of general WMSS as shown in Table 6.

Another significant model for predicting low back WMSS among these cohorts had age, sex, sleep duration and exercise status as its independent variables and explained 36.0 and $96.0 \%$ (Nagelkerke $\mathrm{R}^{2}$ ) of the variance in WMSS of the low back and also correctly classified 82.0 and $98.0 \%$ of these cases for the DGWs and SWD, respectively. Being a female $(\mathrm{OR}=10.26, p=0.021)$, and decreased sleep duration below $6 \mathrm{~h}$ per day $(\mathrm{OR}=0.56$, $p=0.004$ ) were the significant independent predictors of low back WMSS among the DGWs. Contrarily, none of these variables independently predicted low back WMSS among the SWD $(p>0.05)$ as shown in Table 6.

Lastly, a model for predicting WMSS of the shoulder region included gender, age, sleep duration, and exercise status as the independent variable. This model explained 33.0 and $76.0 \%$ (Nagelkerke $\mathrm{R}^{2}$ ) of the variance in WMSS of the shoulder as well as classified 68.0 and $88.0 \%$ of shoulder WMSD cases, respectively, for the DGWs and SWD. Female gender $(\mathrm{OR}=6.98, p=0.046)$, sleep duration less than $6 \mathrm{~h}$ per day $(\mathrm{OR}=0.73, p=$ $0.044)$, and poor exercise habit $(\mathrm{OR}=0.15, p=0.013)$ independently and significantly predicted shoulder WMSS among the DGW. These variables failed to significantly predict shoulder WMSS among the SWD $(p>0.05)$ as shown in Table 6.

\section{Discussion}

The result of the present study showed a significantly higher WMSS prevalence among DGWs than SWD. The data showed that DGWs were twice more prone to developing WMSS than their counterparts in works departments of universities. Personal factors (such as sleep

Table 4 Association between WMSD and selected demographic and cardiopulmonary variables among Domestic Gas Workers and Staff of Works Department $(n=100)$

\begin{tabular}{|c|c|c|c|c|c|c|}
\hline \multirow[t]{3}{*}{ Variables } & \multicolumn{6}{|c|}{$x^{2}$-statistics ( $p$-value) } \\
\hline & \multicolumn{2}{|l|}{ General WMSD } & \multicolumn{2}{|c|}{ Shoulder WMSD } & \multicolumn{2}{|c|}{ Low Back WMSD } \\
\hline & $\mathrm{DGW}(n=50)$ & $\operatorname{SWD}(n=50)$ & $\mathrm{DGW}(n=50)$ & $\operatorname{SWD}(n=50)$ & $\mathrm{DGW}(n=50)$ & $\operatorname{SWD}(n=50)$ \\
\hline Age (years) & $23.67(0.250)$ & $32.31(0.149)$ & $41.70(0.003)^{*}$ & $23.17(0.560)$ & $36.00(0.020)^{*}$ & $50.00(0.002)^{*}$ \\
\hline Gender & $0.04(0.616)$ & $5.53(0.027)^{*}$ & $7.39(0.008)^{*}$ & $1.52(0.240)$ & $8.00(0.006)^{*}$ & $5.36(0.160)$ \\
\hline Height (m) & $7.91(0.849)$ & $10.15(0.602)$ & $27.16(0.012)^{*}$ & $10.97(0.530)$ & $25.00(0.020)^{*}$ & $1.66(1.000)$ \\
\hline Weight (kg) & $24.54(0.268)$ & $14.98(0.777)$ & $22.41(0.376)$ & $19.2(0.500)$ & $22.27(0.380)$ & $11.73(0.930)$ \\
\hline $\mathrm{BMI}$ & $41.69(0.571)$ & $34.44(0.678)$ & $47.99(0.314)$ & $35.79(0.617)$ & $47.97(0.310)$ & $24.49(0.960)$ \\
\hline $\mathrm{SBP}(\mathrm{mmHg})$ & $5.70(0.457)$ & $4.89(0.769)$ & $9.47(0.149)$ & $8.46(0.389)$ & $9.27(0.159)$ & $1.81(0.986)$ \\
\hline $\mathrm{DBP}(\mathrm{mmHg})$ & $20.79(0.004)^{*}$ & $7.27(0.122)$ & $12.60(0.082)$ & $0.93(0.920)$ & $15.10(0.030)^{*}$ & $1.29(0.862)$ \\
\hline $\mathrm{RR}(\mathrm{cpm})$ & $13.71(0.057)$ & $8.02(0.331)$ & $15.85(0.027)^{*}$ & $2.91(0.89)$ & $14.40(0.040)^{*}$ & $2.62(0.917)$ \\
\hline RHR (bpm) & $3.41(0.992)$ & $10.26(0.507)$ & $14.22(0.287)$ & $11.16(0.430)$ & $14.04(0.290)$ & $2.90(0.990)$ \\
\hline
\end{tabular}

DGW Domestic Gas Workers, SWD Staff of Works Department, BMI Body Mass Index, SBP Systolic Blood Pressure, DBP Diastolic Blood Pressure, RR Respiratory Rate, RHR Resting Heart Rate

* = significant (2-tailed) test at $p<0.05$ 
Table 5 Association between WMSD and selected work-related risk factors among Domestic Gas Workers and Staff of Works Department $(n=100)$

\begin{tabular}{|c|c|c|c|c|c|c|}
\hline \multirow[t]{3}{*}{ Variables } & \multicolumn{6}{|c|}{$x^{2}$-stastistics ( $p$-value) } \\
\hline & \multicolumn{2}{|l|}{ General WMSD } & \multicolumn{2}{|l|}{ Shoulder WMSD } & \multicolumn{2}{|c|}{ Low Back WMSD } \\
\hline & $\overline{\mathrm{DGW}}(n=50)$ & $\operatorname{SWD}(n=50)$ & $\overline{\mathrm{DGW}}(n=50)$ & $\operatorname{SWD}(n=50)$ & $\overline{\mathrm{DGW}}(n=50)$ & $\operatorname{SWD}(n=50)$ \\
\hline Daily work duration & $21.06(0.007)^{*}$ & $5.86(0.050)^{*}$ & $12.24(0.141)$ & $4.780(0.090)$ & $13.30(0.101)$ & $0.26(0.880)$ \\
\hline Break & $0.34(0.737)$ & $0.06(0.588)$ & $2.26(0.225)$ & $0.93(0.440)$ & $2.44(0.207)$ & $0.14(0.880)$ \\
\hline Sleep duration & $11.35(0.125)$ & $4.65(0.795)$ & $26.80(<0.001)^{*}$ & $4.19(0.830)$ & $31.3(<0.001)^{*}$ & $3.61(0.890)$ \\
\hline Work shift & $0.90(0.454)$ & $0.22(0.430)$ & $0.14(0.549)$ & $2.37(0.130)$ & $0.08(0.578)$ & $1.66(0.380)$ \\
\hline Work frequency & $2.57(0.277)$ & $9.06(0.011)^{*}$ & $1.74(0.499)$ & $9.17(0.100)$ & $2.97(0.226)$ & $0.11(0.940)$ \\
\hline Year of service & $34.77(0.070)$ & $20.84(0.346)$ & $22.10(0.181)$ & $22.01(0.280)$ & $22.68(0.160)$ & $50.0(<0.001)^{*}$ \\
\hline Lifting training & $2.36(0.036)^{*}$ & $1.67(0.380)$ & $0.00(0.543)$ & $7.48(0.120)$ & $0.05(0.535)$ & $50.00(0.020)^{*}$ \\
\hline Use of PPE(gloves) & $7.64(0.022)^{*}$ & $1.67(0.380)$ & $3.80(0.149)$ & $0.13(0.880)$ & $3.48(0.178)$ & $0.02(0.980)$ \\
\hline Exercise status & $3.49(0.067)$ & $0.88(0.642)$ & $5.51(0.020)^{*}$ & $0.38(0.670)$ & $1.69(1.610)$ & $0.80(0.670)$ \\
\hline
\end{tabular}

DGW Domestic Gas Workers, SWD Staff of Works Department, PPE personal protective equipment

* $=$ significant (2-tailed) test at $p<0.05$

habit and experience) and occupational factors (such as work duration, work frequency, training and use of PPE) were found to differ between the groups, each time DGWs had a higher risk ratio of WMSS than the SWD. A similarly high WMSS prevalence was reported among gas cylinder handlers in Taiwan [6] and was found to be higher than that of the general Taiwanese working population [16]. Also, a significantly greater proportion of the DGWs experienced higher pain intensities (moderate and severe) than the SWD. The present authors opined that the continual and cumulative exposure of the DGWs to WMSS risk factors such as prolonged work duration, poor sleep habits, and increased non-use of PPE may have worsened their WMSS. AlNekhilan et al. [17] supported the thesis that continual exposure of workers to job strain without rest period, worsens their pre-existing WMSS. Therefore, facility managers and administrative officers are advised to allow shift duty, casual leaves, health leaves, and other breaks that could help their staff to recover from job stress or seek health care, when required.

Our findings showed that the average work duration and frequency of DGWs ( $10 \mathrm{~h}$ daily/6 days per week, i.e. $60 \mathrm{~h}$ ) was almost twice the period ( $7 \mathrm{~h}$ daily $/ 5$ days per week, i.e. $35 \mathrm{~h}$ ) reported by the SWD. Most of the DGWs in Enugu operate between 7:00 am and 8:00 pm, similar to petrol station attendants in Nigeria [18]. Comparatively, the majority of the SWD work either on a day shift (8:00 am to 4:00 pm) or night shift (4:00 pm to 8:00 am). Working beyond $8 \mathrm{~h}$ was a significant predictor of

Table 6 Trimmed Regression Models for Predicting WMSD among Domestic Gas Workers and Staff of Works Department $(n=100)$

\begin{tabular}{|c|c|c|c|c|c|c|}
\hline \multirow[t]{3}{*}{ Independent Variables } & \multicolumn{6}{|c|}{ Odds Ratio (p-value) } \\
\hline & \multicolumn{2}{|l|}{ General WMSD } & \multicolumn{2}{|c|}{ Low back WMSD } & \multicolumn{2}{|c|}{ Shoulder WMSD } \\
\hline & $\mathrm{DGW}(n=50)$ & $\operatorname{SWD}(n=50)$ & $\mathrm{DGW}(n=50)$ & $\operatorname{SWD}(n=50)$ & $\mathrm{DGW}(n=50)$ & $\operatorname{SWD}(n=50)$ \\
\hline $\begin{array}{l}\text { Diastolic Blood } \\
\text { Pressure (mmHg) }\end{array}$ & $\begin{array}{l}1.29 \\
(0.018)^{*}\end{array}$ & $\begin{array}{l}0.99 \\
(0.012)^{*}\end{array}$ & - & - & - & - \\
\hline $\begin{array}{l}\text { work duration } \\
\text { (> } 8 \mathrm{~h} / \text { day) }\end{array}$ & $\begin{array}{l}<0.001 \\
(0.028)^{*}\end{array}$ & - & - & - & - & - \\
\hline Gender (female) & $\begin{array}{l}1.13 \\
(0.943)\end{array}$ & $\begin{array}{l}6.47 \\
(0.032)^{*}\end{array}$ & $\begin{array}{l}10.26 \\
(0.021)^{*}\end{array}$ & $\begin{array}{l}0.001 \\
(0.997)\end{array}$ & $\begin{array}{l}6.98 \\
(0.046)^{*}\end{array}$ & $0.22(0.118)$ \\
\hline Age (years) & - & - & $\begin{array}{l}1.07 \\
(0.062)\end{array}$ & $\begin{array}{l}0.97 \\
(0.816)\end{array}$ & $\begin{array}{l}1.04 \\
(0.276)\end{array}$ & $\begin{array}{l}0.95 \\
(0.299)\end{array}$ \\
\hline Sleep duration $(<6 \mathrm{~h})$ & - & - & $\begin{array}{l}0.56 \\
(0.004)^{*}\end{array}$ & $\begin{array}{l}0.93 \\
(0.942)\end{array}$ & $\begin{array}{l}0.73 \\
(0.044)^{*}\end{array}$ & $\begin{array}{l}1.07 \\
(0.791)\end{array}$ \\
\hline Exercise Status (poor) & - & - & - & - & $\begin{array}{l}0.15 \\
(0.013)^{*}\end{array}$ & $\begin{array}{l}3.02 \\
(0.331)\end{array}$ \\
\hline Nagelkerke $\mathrm{R}^{2}$ & 0.76 & 0.22 & 0.36 & 0.96 & 0.33 & 0.68 \\
\hline Classification & $92.00 \%$ & $70.00 \%$ & $82.00 \%$ & $98.00 \%$ & $70.00 \%$ & $88.00 \%$ \\
\hline
\end{tabular}


WMSS of the low back and shoulders among the DGWs. Work settings with longer daily work duration are consistently associated with poor health outcomes. Soe et al. [19] reported that working hours significantly associated with WMSS on Myanmar migrant workers. This report also concurred with another study that found a significant association between long working hours and prevalence of WMSS among Korean workers [10]. Prolonged job duration constitutes a risk of musculoskeletal disorders through several mechanisms. First, it enhances the release of stress hormones such as cortisol, cathecholamines, and vasopressin. Those hormones are capable of inducing muscle fatigue and predisposing the myotomes to microtrauma [20]. Secondly, prolonged job duration increases exposure time to physical demands such as awkward postures, repetitive movements, and heavy lifting that may lead to musculoskeletal injury [4]. Finally, it can cause a relative decrease in rest, leisure, and recovery time. It is therefore recommended that the work set up in domestic gas stations in Nigeria should be restructured to enable shifts of less than $8 \mathrm{~h}$ per day and a rest break during shift duty.

Furthermore, there was an inverse relationship between daily work duration and sleep duration. It seems that workers who put in more hours at work have less sleep time. Sleep duration was found to be a significant predictor of WMSS among the DGWs. Sleep deprivation sets the stage for tissue injury due to increased inflammatory markers such as cortisol (stress hormone), and prostaglandins [21]. After a day's work, there is an increase in stress hormones such as cortisol [22], good sleep helps to modulate these hormones to optimal body functioning level [23]. Therefore, sleep deprivation, leads to an imbalance in these hormone levels and the body tends to malfunction. Moreover, inadequate sleep inhibits the release of human growth hormone [24] that is responsible for repairing damaged tissues thereby prolonging tissue healing time. It is therefore recommended that manual material handlers similar to those of DGWs should sleep for at least $6 \mathrm{~h}$ per day to encourage tissue healing of the microtrauma from the day's work and prevent inflammatory tissue injury.

The need for continuous ergonomics training on lifting techniques for DGWs cannot be overemphasised. A piece of historical evidence has shown that carrying out a task without training imposes musculoskeletal stress with a detrimental effect on human anatomy and physiology [25]. Additionally, PPE such as gloves and boots can help in preventing direct contact forces capable of causing soft tissue injuries. Similar to the present study, scholars have proposed that compliance with the use of PPE reduces the risk of WMSS [26]. Moreover, the use of assistive devices such cylinder trolley and forklift can reduce the physical demands on DGWs.
In terms of body regions, WMSS was most common in the low back, and shoulders among the DGWs but highest around the hips and thighs among the SWD. This outcome appears congruent with the job description of these two groups. Task analysis for DGWs revealed stationary lifting of heavy cylinders and short distance transfer. These activities engage the antigravity muscles of the shoulders and the lower back stabilisers and continuous exposure to these factors may culminate in a shoulder and low back WMSS. On the other hand, the SWD appear to engage more in routine transfer of lighter objects to distant substations, with resultant overuse of the ambulatory (hip and thigh) muscles. A review of WMSS by the National Institute of Occupational Safety and Health (in the USA) found strong evidence that low back disorders are related to forceful lifting and weight of the load lifted [27] as was commonly seen among the DGWs. Based on these findings, lumbar core strength and stability exercises are recommended for DGWs while passive stretching and strengthening of the hip and thigh muscles are recommended for the SWD.

Furthermore, the present study identified a few demographic and work-related risk factors associated with the occurrence of general WMSS among the participants. There was a preponderance of male in both groups, presumably, due to the manual handling demands of these jobs. Similarly, higher proportion of male workers have been reported in other jobs requiring manual material handling such as construction work [28, 29], commercial driving [30, 31], and farming [32]. Among the SWD, significant associations were observed between general WMSS and each of gender, work frequency, and diastolic blood pressure. The Works Department in most tertiary institutions in Nigeria have various subunits such as carpentry, welding, wiring, construction, automobile, plumbing, environmental services, and general maintenance [11]. These manual and high energy demanding tasks may be unsuitable for the female workforce, considering some socio-cultural and physiological barriers. Therefore engaging female workers in these tasks may heighten the risk of WMSD among this cohort. In addition, being a female was reported as a predictor of general WMSS among SWD in this current study. This appears to be corroborated by the reports of Park et al. [33] who in their study among Korean workers reported that sex difference in WMSD depends on the different work sectors. Aside from the physical job demands, Josephson et al. [34] went further and opined that being a woman can be a risk factor for WMSD independent of the exposure situation. In a study carried out among workers in New Zealand, females had a significantly higher WMSD prevalence compared to males [35]. From the authors' anecdotal knowledge, home chores and childcare imposes 
additional musculoskeletal stress on the typical Nigerian woman beyond the work environment. It is therefore recommended that extra attention should be paid to the female workers. Labour unions and government agencies should ensure that antenatal and maternity leaves are granted as prescribed in labour regulations. Duty rosters can be adjusted to accommodate workers who have other family and social roles such as childcare, school run, and home upkeep. Moreover, these work settings should enrol their staff in a health insurance scheme and ensure regular medical checks among the personnel.

The report of general WMSS among the DGW was associated with higher diastolic blood pressure, inadequate training on proper lifting techniques, and noncompliance with the use of PPE. Conversely, the SWD were not affected by these factors. This could be because the SWD worked in a formal setting (university and hospital environments), with access to healthcare, continuous professional training, and under firm occupational guidelines and supervision. Johansson et al. [36] reported that increased job stress among Swedish drivers correlated with elevated diastolic blood pressure and a higher prevalence of musculoskeletal pain. More so, diastolic blood pressure was a predictor of WMSS among the study participants. It is, therefore, necessary to regularly evaluate the blood pressure of workers as a direct measure of job strain and by extension, a correlate of musculoskeletal symptoms especially among workers with similar job tasks as DGWs.

There was no significant association between general WMSS and exercise status; however, poor exercise habit was an independent predictor of shoulder WMSS among the DGWs. The job task of the DGWs was seen to be characterized by heavy lifting and carrying of filled gas cylinders. These activities expose the shoulder joints to repeated traction forces that may increase shoulder instability and thus result in shoulder MSDs. To counteract this effect, it is required that the shoulder muscles especially the deltoid and rotator cuff muscles (supraspinatus, infraspinatus, teres minor, and subscapularis) should be regularly strengthened through resistant (muscle building) exercises. The DGWs who were unaware of this job risk factor, shoulder biomechanics, and benefits of shoulder muscle strengthening exercises, may present with shoulder WMSS. Serra et al. [37] indicated that physical exercise helped to reduce the risk of WMSS in a (Brazilian) workplace when compared with workers who did not engage in physical exercise and opined that exercise prepares workers against strenuous musculoskeletal demands. Workers should have a recreational period when they can engage in muscles-specific structured (resistant) exercises.

\section{Limitations}

The participants were not randomly selected which could lead to distribution bias - affecting the generalisability of the findings. We were not able to control for possible extraneous variables such as domestic and recreational risk factors of WMSS.

\section{Conclusion}

There is a high prevalence of WMSS among workers in domestic gas stations, significantly higher than those of their counterparts in the works departments of tertiary institutions. Low back and shoulder WMSS are more common among DGWs while thigh and hip WMSS are the most frequent WMSS among SWD. Stress indicated by high diastolic blood pressure, working greater than 8 $\mathrm{h}$ per day, female gender, sleep deprivation beyond $6 \mathrm{~h}$ per day, and poor exercise habits are the independent risk factors of WMSS among these cohorts. Therefore, SWD and DGWs require break and leave periods, PPE, assistive devices, exercise, medical check-up, and ergonomically designed workplace. A comprehensive and continuous ergonomics evaluation and training for both managerial and non-managerial staff of domestic gas stations, and institutional works departments is recommended. Also, the labour unions in Nigeria should ensure that workers in these sectors operate within the confines of healthy occupational guidelines.

\section{Abbreviations \\ BMI: Body Mass Index; DBP: Diastolic Blood Pressure; DGW: Domestic Gas Workers; MSD: Musculoskeletal Disorders; NMQ: Nordic Musculoskeletal Questionnaire; NPRS: Numerical Pain Rating Scale; PPE: Personal Protective Equipment; RHR: Resting Heart Rate; RR: Respiratory Rate; SBP: Systolic Blood Pressure; SPSS: Statistical Package for Social Sciences; UNEC: University of Nigeria Enugu Campus; UNTH: University of Nigeria Teaching Hospital; USA: United States of America; WMSS: Work-related Musculoskeletal Symptoms}

\section{Acknowledgements}

The authors would like to thank the staff and management of domestic gas workers and works departments in Enugu, Nigeria where this study was conducted for approving and/or participating in this study.

\section{Authors' contributions}

$\mathrm{CDO}, \mathrm{EO}, \mathrm{OAE}$, and ENDE contributed to the conception of this study. CDO, $\mathrm{EO}, \mathrm{OAE}, \mathrm{OKO}$, and ENDE made substantial contributions to the design, acquisition of data, and performed the statistical analysis. CDO, EO, OKO, and ENDE were responsible for drafting the article. CDO, OKO, and ENDE contributed to its critical revision. All authors approved the final manuscript for publication. All authors have agreed to be personally accountable for the author's contributions and ensure that questions related to the accuracy or integrity of any part of the work, even ones in which the author was not personally involved, are appropriately investigated, resolved, and the resolution documented in the literature.

\section{Funding}

There was no external funding for this study.

Availability of data and materials

The questionnaire used and datasets analysed during the current study are available from the corresponding author on reasonable request. 


\section{Ethics approval and consent to participate}

Ethical approval for this study was obtained from the Health Research Committee of the University of Nigeria Teaching Hospital, Enugu State, Nigeria. The objectives of the study were clearly explained in the informed consent form and endorsed by each participant.

\section{Consent for publication}

Not applicable.

\section{Competing interests}

The authors declare that they have no competing interests.

\section{Author details}

${ }^{1}$ Physiotherapy Department, Medical Center, University of Nigeria Enugu Campus, Enugu, Nigeria. ${ }^{2}$ Department of Medical Rehabilitation, Faculty of Health Sciences and Technology, College of Medicine, University of Nigeria, Enugu, Nigeria. ${ }^{3}$ Department of Physiotherapy, Nnamdi Azikiwe University Teaching Hospital, Nnewi, Nigeria. ${ }^{4}$ Department of Physiotherapy, Faculty of Health Sciences, Bayelsa Medical University, Yenagoa, Nigeria. ${ }^{5}$ LANCET Physiotherapy Wellness and Research Centre, Enugu, Nigeria.

\section{Received: 17 March 2020 Accepted: 27 August 2020}

\section{Published online: 01 September 2020}

\section{References}

1. Connelly LB, Woolf A. Brooks P. In: Jamison DT, Breman JG, Measham AR, Alleyne G, Claeson M, Evans DB, et al., editors. Disease control priorities in developing countries. 2nd ed. Washington (DC): World Bank; 2006.

2. Bihari V, Kesavachandran C, Pangtey B, Srivastava A, Mathur N. (2011) musculoskeletal pain and its associated risk factors in residents of the National Capital Region. Indian J Occup Environ Med. 2011;15(2):59-63. https://doi.org/10.4103/0019-5278.90375.

3. Tinubu BMS, Mbata C, Oyeyemi AL, Fabunmi AA. Work-related musculoskeletal disorders among nurses in Ibadan south-west, Nigeria A cross-sectional survey. BMC Musculoskelet Disord. 2010;11:12. https://doi. org/10.1186/1471-2474-11-12

4. Alireza C, Nathan C. Baylor, Samson a. prevalence and risk of musculoskeletal disorder in manual workers. Occupational Health. 2007;34: 456-60.

5. Abo-Salem MA, Mahrous OA, Kasemy ZA, Allam HK, Mohsen M. Prevalence and risk factors of musculoskeletal disorders among natural gas field workers. Egypt J Hosp Med. 2017;41(1):19-33.

6. Chen YL, Yu CY, Lin DA. Musculoskeletal disorders caused by gas-cylinder handling tasks: a case study report. Work. 2017;56(3):403-7. https://doi.org/ 10.3233/WOR-172506.

7. Zamil A, Yaacob MI, Zulkapli MHI, Shaari MR, Damairi RN, Deros BM, et al. (2018) risk factors for musculoskeletal disorders in liquified petroleum gas bottling plant - a case study. Hum Factors Ergon J. 2018;3(1):8-11.

8. Adegoke BOA, Akodu AK, Oyeyemi AL. Work-related musculoskeletal disorders among Nigeria physiotherapists. BMC Musculoskelet Disord. 2008; 18(8):9-112. https://doi.org/10.1186/1471-2474-9-112.

9. Chen YL. Gas-cylinder handling tasks in Taiwan. Occup Med Health Aff. 2016;4:232. https://doi.org/10.4172/2329-6879.1000232.

10. Lee JG, Kim GH, Jung SW, Kim SW, Lee KJ, Lee KJ. Association between long working hours and work-related musculoskeletal symptoms of Korean wage workers: data from the fourth Korean working conditions survey (a crosssectional study). Ann Occup Environ Med. 2018;30(12):67. https://doi.org/10. 1186/s40557-018-0278-0.

11. University of Nigeria. [internet]. Works: Works Services Department; 2020. [Retrieved on 2020 Mar 31] Available from https: //www.unn.edu.ng/ administration/administrative-support-units/works/.

12. Ezema Cl, Omeh E, Onyeso OKK, Anyachukwu CC, Nwankwo MJ, Amaeze A, et al. The effect of an aerobic exercise programme on blood glucose level, cardiovascular parameters, peripheral oxygen saturation, and body mass index among Southern Nigerians with type 2 diabetes mellitus, undergoing concurrent sulfonylurea and metformin treatment. Malays J Med Sci. 2019; 26(5):88-97. https://doi.org/10.21315/mjms2019.26.5.8.

13. Kuorinka I, Jonsson B, Kilbom A, Vinterberg H, Biering-Sørensen F, Andersson G, et al. Standardised Nordic questionnaires for the analysis of musculoskeletal symptoms. Appl Ergon. 1987;18(3):233-7. https://doi.org/10. 1016/0003-6870(87)90010-X.
14. Deakin J, Stevenson J, Vail G, Nelson J. The use of the Nordic questionnaire in an industrial setting: a case study. Appl Ergon. 1994;25:182-5.

15. Anyachukwu CC, Onyeso OKK, Ezema Cl. Age, body mass and physical activity determinants of facial acne severity among Southern Nigerian adolescents and young adults. W Indian Med J. 2018;5(2):66-71. https://doi. org/10.7727/wimj.2017.162

16. Guo HR, Chang YC, Yeh WY, Chen CW, Guo YL. Prevalence of musculoskeletal disorder among workers in Taiwan: a nationwide study. J Occup Health. 2004;46(1):26-36.

17. AINekhilan AF, AlTamimi AM, AlAqeel BY, AlHawery AA, AlFadhel SF, Masuadi EM. Work-related musculoskeletal disorders among clinical laboratory workers. Avicenna J Med. 2020;10(1):29.

18. Johnson OE, Umoren QM. Assessment of occupational hazards, health problems and safety practices of petrol station attendants in Uyo, Nigeria. J Commun Med Prim Health Care. 2018;30(1):47-57.

19. Soe KT, Laosee O, Limsatchapanich S, Rattanapan C. Prevalence and risk factors of musculoskeletal disorders among Myanmar migrant workers in Thai seafood industries. Int J Occup Saf Ergon. 2015;21(4):539-46. https:// doi.org/10.1080/10803548.2015.1096609.

20. Hannibal KE, Bishop MD. Chronic stress, cortisol dysfunction, and pain: a psychoneuroendocrine rationale for stress management in pain rehabilitation. Phys Ther. 2014;94(12):1816-25.

21. Periasamy S, Hsu DZ, Fu YH, Liu MY. Sleep deprivation-induced multi-organ injury: role of oxidative stress and inflammation. EXCLI J. 2015;14:672-83. https://doi.org/10.17179/excli2015-245.

22. De Sio S, Letizia C, Petramala L, Saracino V, Cedrone F, Sanguigni $P$, Buomprisco G, Perri R, Trovato Battagliola E, Mannocci A, La Torre G. Workrelated stress and cortisol levels: is there an association? Results of an observational study. Eur Rev Med Pharmacol Sci. 2018;22(24):9012-7.

23. Scher A, Hall WA, Zaidman-Zait A, Weinberg J. Sleep quality, cortisol levels, and behavioral regulation in toddlers. Dev Psychobiol. 2010;52(1):44-53.

24. Backeljauw P, Hwa V. Growth hormone physiology. In: Growth hormone deficiency. Cham: Springer; 2016. p. 7-20.

25. Nwuga VCB. Manual treatment of back pain. Ibadan: Shaneson; 1990.

26. Shih $\mathrm{RH}$, Vasarhelyi EM, Dubrowski A, Carnahan $\mathrm{H}$. The effects of latex gloves on the kinetics of grasping. Int J Ind Ergon. 2001;28(5):265-73. https://doi.org/10.1016/S0169-8141(01)00021-X.

27. Putz-Anderson V, Bernard BP, Burt SE, Cole LL, Fairfield-Estill C, Fine LJ. Musculoskeletal disorders and workplace factors: a critical review of epidemiologic evidence for work-related musculoskeletal disorders of the neck, upper extremity, and low back. [Internet] NIOSH. 1997:97-141 [Retrieved on 2019 May 14]. Available from: http://www.cdc.gov/niosh/ docs/97-141/pdfs/97-141.pdf.

28. Reddy GM, Nisha B, Prabhushankar TG, Vishwambhar V. Musculoskeletal morbidity among construction workers: a cross-sectional community-based study. Indian J Occup Environ Med. 2016;20(3):144.

29. Jasani PK, Nimavat JH, Joshi JB, Kartha GP. A study of morbidity profile amongst construction workers at selected construction sites in Surendranagar city. Int J Med Sci Public Health. 2017;6(2):382-7.

30. Hakim S, Mohsen A. Work-related and ergonomic risk factors associated with low back pain among bus drivers. J Egypt Public Health Assoc. 2017; 92(3):195-201.

31. Ekechukwu EN, Okaku MO, Adaramola S, Onuorah IN. Patterns and Predictors of Work-Related Musculoskeletal Disorders Among Commercial Tricycle (Keke Napep) Riders in Nigeria. In: Congress of the International Ergonomics Association. Cham: Springer; 2018. p. 765-77.

32. Patil SA, Kadam YR, Mane AS, Gore AD, Dhumale GB. The prevalence and health impact of musculoskeletal disorders among farmers. Med J Dr DY Patil Vidyapeeth. 2018;11(6):485.

33. Park JH, Hong JY, Han K. Prevalence of symptomatic hip, knee, and spine osteoarthritis nationwide health survey analysis of an elderly Korean population. Medicine. 2017;96:e6372.

34. Josephson M, Pernold G, Ahlberg-Hulten G, Theorell T, Vingard E, Waldenstreom $\mathrm{M}$, et al. Differences in the association between psychosocial work condition and physical workload in female and male-dominated occupation. Am Ind Hyg Assoc J. 1999;60:673-8.

35. Widanarko B, Legg S, Stevenson M, Devereux J, Eng A, Mannetje AT. Prevalence of musculoskeletal symptoms in relation to gender, age, and occupational/industrial group. Int J Ind Ergon. 2011;41:561-72. https://doi. org/10.1016/j.ergon.2011.06.002. 
36. Johansson G, Evans GW, Cedestrom L, Rydstedt LW, Fuller-Rowell T, Ong AD. Effects of urban bus driving on blood pressure and musculoskeletal problem. Psychosom Med. 2012;74(1):89-92. https://doi.org/10.1097/PSY Ob013e31823ba88f.

37. Serra MVGB, Camargo PR, Zaia JE, Tonello MGM, Quemelo PRV. Effects of physical exercise on musculoskeletal disorders, stress and quality of life in workers. Int J Occup Saf Ergon. 2018;24(1):62-7. https://doi.org/10.1080/ 10803548.2016.1234132.

\section{Publisher's Note}

Springer Nature remains neutral with regard to jurisdictional claims in published maps and institutional affiliations.

Ready to submit your research? Choose BMC and benefit from:

- fast, convenient online submission

- thorough peer review by experienced researchers in your field

- rapid publication on acceptance

- support for research data, including large and complex data types

- gold Open Access which fosters wider collaboration and increased citations

- maximum visibility for your research: over $100 \mathrm{M}$ website views per year

At $\mathrm{BMC}$, research is always in progress.

Learn more biomedcentral.com/submissions 